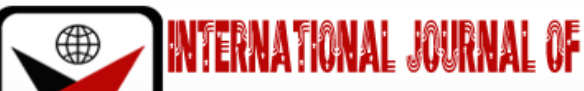

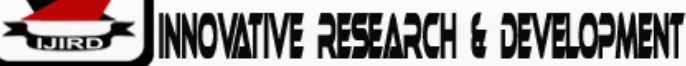

ISSN 2278-0211 (Online)

\section{The Roller Coaster Life in Teaching: The Case of Pre-service Teachers in a State University}

\author{
Fabiana P. Peñeda \\ Instructor, Integrated Laboratory School, Leyte Normal University, Philippines
}

\begin{abstract}
:
Teachers are honed for many years to be able to teach comprehensively to diverse learners. Before achieving college diplomas, they still have to undergo practice teaching to enhance and employ content and pedagogical approaches they learned from their previous college years. This study's framework was based clearly on Jean's Piaget Formal Operational Stage and Albert Banduras' Social Cognitive Development Theory. Learners develop their critical thinking during a formal stage, promoting constructive behavior that affects an individual's success. Ten (10) elementary preservice teachers of a laboratory school were selected through the purposive sampling technique. The researcher gathered the data appropriately using in-depth semi-structured interviews, and responses were recorded and documented with confidentiality. This study's findings are the pre-service teachers' preparation stage of teaching, tangible teaching exposure, utilization of pedagogical methods and approaches, people's unamenable behavior, vigorous school demands, financial shortage, implementation of diverse teaching strategies, possess adequate personality and seek out spiritual guidance. Results suggest that school administrators and faculty educators must provide all education students with resilient and concrete experiences. Lesson planning, various teaching strategies, and classroom management must introduce as early as possible once they step into the education portal during their first year in college before undergoing the practice teaching stage.
\end{abstract}

Keywords: Education, pre-service teachers, qualitative case study, formal operational stage, social cognitive development theory

\section{Introduction}

Practice teaching is the final phase for all education students. It is an education course where preservice teachers experience various actual experiences where social and cognitive aspects are challenged academically. These factors influence their actual demonstration performance in lesson planning, classroom management, and teaching strategy. According to the international study of Sharma et al. (2006) revealed that university that offers education courses must ensure a strong foundation in the pedagogical methods and approaches which produces emotionally stable, critical thinker and competent future educator teachers. In the Philippines, the National Competency-Based Teachers' Standard (NCBTS) is one of the foundations that give an extensive range of planning and managing preservice teachers' teaching experiences and help them in their actual performance (Visande, 2014). Annually, many education students are successfully graduating. Preservice teachers surpass all that hinders them during their practice teaching. Many research types have been done, but no in-depth exploration about the practice teaching experiences of elementary preservice teachers in an educational institution in Region VIII.

The classroom is where preservice teachers' actual teaching occurs, but some of them cannot grasp the teaching methodologies and approaches immediately during preservice teaching in a short period (Ulla, 2016). Self-reliance and assistance from the experts are necessary to achieve success in teaching training. Preservice teachers' self-reliance helps them endure the most challenging task during the entire teaching practice. Assistance from the supervising teacher educators, pupils, and parents are needed most to continue their training, but with the lack of support and self-reliance, everything will fall apart (Specht et al., 2016). The purpose of this study is to explore the various experiences of practice teachers, such as their perspectives, challenges encountered, and coping mechanisms during the practice teaching period. This study is essential because preservice teachers are future educators who will teach the future generation with confidence and precise information. The findings can also help the education institution strengthen their preservice teachers' pedagogical methods and approaches. Moreover, this study also helps the teaching supervisors to allow the education students to expose themselves to all related actual classroom tasks and be familiar with the setting in a school set up before practice teaching.

\section{Theoretical Framework}

This study is based on the two famous theories, which are Formal Operational Stage-Cognitive Development theory of Jean Piaget and Social Cognitive development of Albert Bandura. 
Piaget (1972) defines the formal operational stage as the final stage of an adolescent's cognitive development to adulthood, which develops a critical thinking ability for an individual. Ahmad et al. (2016) define the formal operational stage as the stage where young learners can share their perspectives towards a particular topic. In this stage, they also involve themselves and handle it carefully without hesitation, emphasizing more things critically. In addition, formal operational stage is where learners have the ability to think critically about particular skills and practices, which signify vigilant procedure of investigation, intellectual analysis and reasonable judgment (Visande, 2014).This theory connects to the preservice teachers' experiences during the practice teaching period since preservice teachers must use higher-order thinking skills to improve performance in terms of teaching approaches and practices. Dealing with the challenges encountered also needs a high cognition in teaching training to develop solutions of ideas.

Bandura (1999) also explains social cognitive theory as an effect of thought and feeling that can be manifested in his acts that can affect the environment. Luszczynska \& Schwarzer (2005) emphasize that social cognitive theory is a kind of self-appreciation by doing and thinking positively. It helps individuals to believe in their abilities and capabilities to attain desirable results of their actions. Social cognitive development states positive reinforcement from the environment that can promote constructive behavior, affecting the progress in a person's cognitive area (Ogunsola et al., 2014). This CST is evident in the study since preservice teachers' actions, and performance can affect the surrounding area. This kind of environment can affect the thinking style of the preservice teacher through a cheerful disposition.

Observing and ensuing these theories helped young preservice teachers think critically with the plans, be positive in life, and be more productive, which entails the achievement they get from doing what is right and can motivate themselves without force. These future generations of teachers will be more competitive, effective, and efficient in their chosen field with the educators' correct guidance in terms of perspectives, challenges they encountered, and coping mechanisms during their practice teaching.

\section{Review of Related Literature}

Practice teaching is when preservice teachers undergo the most critical aspect of being a teacher (RakiciogluSoylemez \& Eroz-Tuga, 2014). Mapfumo \& Chitsiko (2012) stresses practical instruction is a process in which they are allowed to show what they have mastered in terms of material and pedagogical abilities and techniques they have gained in previous years of study. Preservice teachers have completed the required courses before receiving instruction in actual teaching (Kennedy \& Archambault, 2012). They are potential teachers going through a period in which they will experience multiple teaching methodologies and methods as a framework and training for education.

The training of teachers for teaching and instructional experiences shapes a structure that is, at the same time, part of the general education system of the graduate of higher education (Matvienko, 2014). Extensive instruction in teaching pedagogy and experience has proven to be more successful than any or no preparatory education in developing fully certified beginning teachers (Boe et al., 2007). This recruitment method, training, and preparation of highly skilled and competitive experts must be closely related to the ongoing reforms' requirements (Yarmatov et al., 2020). It is a radical idea to put severe and sustained teacher preparation at the forefront of school reform (Feiman-Nemser, 2001). The successful implementation of teacher education courses in the survey conducted by Shaukat et al. (2013) for Pakistani and Australian preservice teachers must ensure that novel teaching alumni have the requisite teaching knowledge, techniques, and approaches.

In Turkey, the higher institution developed education programs essential for preservice teachers' teaching experiences to help them have adequate experiences to construct skills and abilities in teaching (Unal et al., 2017). Teacher preparation systems were the first technical attempt to describe completed education significantly impacting standardization (Darling-Hammond, 2008). The development of PDK was affected mainly by the preservice teachers' teaching experience (Van Driel et al., 2000). Furthermore, significant educational experiences and field-based instruction provide opportunities for teachers to build their personalities and to develop their awareness of social issues (Chen \& Mensah, 2018). Some of the strongest influences on teachers' development are teaching experiences during fieldwork (Johnson,2010). The teachers' teaching experience in schools today also shows the vulnerability and turmoil because they are inexperienced with modern education and planned activities (Riedler \& Eryaman, 2017).

Teaching strategies denotes the different approaches and techniques used to improve achievable objectives, support, and acquire the learners' desired contents (Innovate My School, 2013). Friedman et al. (2011) emphasize that to have good teaching demands meaningful use of teaching strategies and approaches to transmit knowledge of subject matter for education. Progress in the methods and instructional strategies helps prepare the preservice teachers (Zeichner,1987) and use practical tools suitable in teaching (Grossman et al., 2009). Also, Mann (2006) states that teachers who use effective strategies help academically challenge learners to have a successful and positive learning environment (Mann, 2006), thus, making learning more meaningful and productive.

In particular, Mapfumo \& Chitsiko (2012) discuss the stressors that can drive preservice teachers to quit teaching training in terms of an unfriendly classroom environment, paperwork, and financial shortcomings. Stuart \& Thurlow (2000) also pointed out that they also faced various forms of difficulties, such as an inaccessible supervisory teacher, pupils' poor manners, parents' requests, and autonomy loss. In the research carried out in Evans (2013), preservice teachers continue to report that their biggest challenge is to develop parent's connections (Harris et al., 2004) and communities. On the other hand, school work, including the daily planning of lectures, teaching materials, and events relating to schools, are essential tasks that add to the challenges they encountered during their practicum, which they need to perform daily. Therefore, teaching practical instruction is one of the most challenging teaching schools (Grossman et al., 2009). Rieg et al. (2007) explain that teaching is one reason why fifty percent of preservice teachers quit. Despite this scenario, it is so important that educators can denote effective coping mechanisms not to develop this kind of decision- 
making. Engaging oneself in a coping mechanism is necessary for daily experiences in teaching. Coping mechanisms can be a form of interaction between the social support system and family members (Mapfumo et al., 2012).

Scaffolds coming from the experts regarding how to gain the best techniques and methods in teaching can help preservice teachers have a deeper understanding of a particular strategy. They must inculcate the benefits of teaching strategies in the field of teaching. Professional Education Teachers are obliged to clearly and profoundly teach the different kinds of teaching strategies to their education students. Preservice teachers assume that teacher education courses offer ample methods and techniques to create meaningful, efficient, and practical instruction (Wilcox et al., 1991). Hence, it can enhance more their teaching skills.

According to Brush \& Saye (2009), it is essential to introduce different kinds of strategies to preservice teachers to provide the specific skills and practices, most especially incorporating technology in teaching. In the same way, practice teachers demonstrate a high quality of instruction using effective techniques (Shulman, 1987). Many researchers said that effective teaching strategies like the use of games, songs, and stories in a particular lesson could promote collaboration and active participation of the pupils. Different teaching strategies can intensify the long-attention span, promote a dynamic classroom environment, and develop creative imagination and higher thinking skills (Ten Dam \& Volman, 2004). Professional teacher educators create holistic experiences for all preservice teachers in the field of education.

One of the essential experiences given to them during their practice teaching is lesson planning. A lesson plan is a daily well-prepared narrative description of the subject matter used as a guide of the teachers during the delivery of an efficacious instruction (Farrell, 2002; Nasari \& Heidari, 2014). Likewise, it helps preservice teachers maintain an effective classroom atmosphere and improve their pedagogical content knowledge (Rusznyak \& Walton, 2011; Shen et al., 2007). Lampert (2010) said that preservice teachers must create lesson plans and have in-depth understanding of their lessons to teach them well. Lesson plans are monitored and checked by the knowledgeable supervising teacher educators that served as scaffolds during their training. Supervising teacher educators are the ones who match, guide, and explain the necessary revisions of preservice teachers' daily lesson plans.

Control in the classroom is a significant problem for beginners, including teachers (Putman, 2009). Nevertheless, preservice teachers have a deep conviction in their teaching area, and they will have a successful outcome in their practicum period. Rosas \& West (2009) concluded that preservice teachers must have the expertise to create a positive and safe learning environment that promotes student excellence with experienced teachers who will guide them in actual teaching. The preservice teachers' classroom techniques are effective when they prefer an approach that will allow them to have confidence in their education training (Reupert \& Woodcock, 2010). Utilizing differentiated instruction in classroom management engages the classroom atmosphere and builds innovative and higher cognitive skills (Ten Dam \& Volman, 2004).

An analysis of professional education requirements indicates that teachers must qualify in three aspects; knowledge, personality, and performance (McDonnough \& Matkins, 2010). Character gives impact to the preservice teachers' training since it helps them surpass challenges encountered. The latest research indicates that a supportive educational atmosphere is essential for preserving teacher education since it provides them with good results that support them in challenging times (Chao et al., 2016). Self-worth is the service teachers' capacity to efficiently and effectively engage learning in their current cognitive level towards their school works and teaching demonstration (Kormos \& Nijakowska,2017). Teaching training is a complex task that will consume your energy and patience of preservice teachers. Attitude generally is a pattern, an activity, a response that can be an indicator to be understood and examined that distinguishes choice. It acts (Alieto et al., 2020) that the work of conservation teachers in their self-efficiency improves as they put effort into teaching (Peebles and Mendaglio (2014).

Having a strong faith in challenging times helps pre-service teachers overcome their educational challenges (White, 2009). Strong faith makes an individual more productive and creative in the task given. Subedi (2006) believes that their strong belief strongly influences preserves teachers in times of difficulty in their actual performance. Mark et al. (2014) highlight that having God's encouragement makes it necessary for people to be optimistic and do good things in life. Being in a practicum, one can experience many hindrances such as schoolwork and pressures given by the people around them. Consequently, strong religious traditions can connect oneself to divine guidance believing that success will be achieved soon in relation towards the experiences of the preservice teachers.

\section{Research Questions}

This single descriptive case (Ferguson \& Peterson, 2002) study intended to explore and identify the perspectives, teaching/instructional strategies, challenges, and coping mechanisms by the preservice teachers on practice teaching. This study would like to answer the following research questions specifically;

- How do preservice teachers view practice teaching?

- What difficulty do preservice teachers encounter in practice teaching?

- How do the preservice teachers deal with the challenges in practice teaching?

\section{Methodology}

\subsection{Research Design}

This study utilized a qualitative case study and employed to explore the perspectives of preservice teachers, the challenges they encountered, and how they deal with the challenges during their practice teaching in a laboratory school. It validated how selecting the participants and setting preferred, described collected data, and followed steps appropriately to strengthen the results' reliability. 


\subsection{Research Participants}

The researcher used purposive sampling techniques to identify ten (10) preservice teachers' participants in the study. Preservice teachers were elementary teachers enrolled officially in Leyte Normal University for School Year 2019 2020. They completed their teaching cycle of instruction and were recommended by their supervisor of practice teaching for dialogue and observation.

\subsection{Research Locale}

This study was conducted in a university in Leyte, knowingly producing excellent and competent future educators in Tacloban City. The researcher has selected this university since it is the center of excellence in producing future teachers in Region VIII.

\subsection{Data Collection and Instrument}

The researcher is interested in their preservice teachers' perspectives on practice teaching, various challenges they encountered, and how they deal with their problems during practice teaching. This study uses the following gathering tools: semi-structured interview, audio-recordings, semi-structured questionnaire, picture taking, and observation during their demonstration teaching. A semi-structured interview is acquiring information about the perspectives, challenges encountered and how they deal with the challenges during their practice teaching. Audio-recordings will help to have a precise record of the interview. The researcher used semi-structured interview guides and solicited answers and information given by the participants during the interview. Observation and picture taking during the teaching demonstration can help strengthen the study's reliability and authenticity, serving as real evidence.

The researcher tells the interview's purpose and seeks consent before recording the dialogues. Participants were encouraged to talk freely and say their experiences during teaching using multilingual languages. The researcher will also seek information from the supervising teacher educators of the preservice teachers for further details during practice teaching. Afterward, the researcher will tell the participants. About giving back the transcribe data and letting them check the conversation to ensure the interview's validity and reliability accurately. All data and information are kept confidential.

\subsection{Data Analysis}

The investigator analyzed the data obtained in the interpretation of data through the bracketing exercise that adopted the Wa-Mbaleka (2018) data analysis process. Precisely, the following ten (10) steps have been taken: plan and organise your data, read your transcripts (or go through your data) once or twice, build your coding manual, code all your data, locate repetitive concepts, abstract your feelings, compose all your data analysis, write your report, check your results and finish and make final revisions.

\section{Results and Discussion}

This study was to identify the perspectives, challenges encountered, and coping mechanisms of the preservice teachers during their practice teaching. This research study centered on the elementary preservice students' teaching experiences in the Laboratory school within Tacloban City. To investigate the relational approach to retaining teachers' perspectives in a laboratory school, the researchers used semi-structured guides or questionnaires. There were eight significant themes namely: Preparation stage of teaching, Tangible teaching exposure, Utilization of pedagogical methods and approaches, People's unamenable behavior, Vigorous school demands, Financial shortage, and Implementation of diverse teaching strategies, possess adequate personality, and seek out spiritual guidance.

Before being an educator, preservice teachers must have competent and flexible teaching methodologies and strong foundation during their practicum. Possessing strong character during internship enhances their teaching ability and potential, particularly when school workloads overlap. McDonnough \& Matkins (2010) stressed that during practice teaching, numerous school demands urge preservice teachers to perform activities with perseverance and dedication so that during their actual presentation, they can enable their learners to understand the lessons better. Indeed, Peebles and Mendaglio said that in teaching, self-efficiency increases commitment.The explicit aspect affecting preservice teachers' teaching performance matters in possessing a good personality since preservice teachers should find effective teaching methods and tools in a creative and resourceful manner.

\subsection{Preservice Teachers' Perspectives on Practice Teaching}

\subsubsection{Theme 1: Preparation Stage of Teaching}

Some of the preservice teacher participants agreed that it is imperative to undergo practice teaching to apply the learnings they learned before and discover how it will help them enormously in the future. Furthermore, Grossman et al. (2009) define practice teaching as a preparatory stage where preservice teachers can think of an authentic teaching scenario.

"Practice Teaching is something that every education students has got to experience before going to the real world of teaching". [P1, L2, P1]

"Practice Teaching is a prerequisite or preparatory wherein you experience and apply the knowledge you learned and taught in school". [P8, L16, P1]

"Practice teaching is about a training for us because we all know that in the near future, we can use what we have learn during our practice teaching". [P4, L8, P1] 


\subsubsection{Theme 2: Tangible Teaching Exposure}

Practice teaching gives exposure to where practice teachers can impart the teaching strategies they learned and feel the actual classroom setting (Kiggundo, 2007). They can feel the importance of prior learnings that will be used in the actual demonstration. It is also the phase where they can improve and discover the teaching strategies they are comfortable with and dedicated to becoming teachers.

"It is like learning through first-hand experience". [P7, L15, P1]

"Practice teaching is the highlight part of a teaching course. It is the time that the students who are taking up education course will experience the actual teaching environment and giving chance to experience the real situation of being a real teacher". [P5, L10, P1]

"Practice is a way to practice the things that are done by a teacher in a 4 corner room and its profession which is teaching". [P6, L14, P1]

\subsubsection{Theme 3: Utilization of Pedagogical Methods and Approaches}

Zeichner (2012) said that it is better to emphasize the instructional practices that contribute to the practice teacher's welfare. He further noted that ". It is part of a growing literature on making teaching practice the central element of teacher education, an approach that has been referred to as practice-based, and practices focused or practice-centered teacher education".

"Most important part of becoming a teacher, stage where we are going to apply our knowledge in teaching". [P9, L19, P1]

\subsection{Preservice Teachers' Challenges Encountered}

\subsubsection{Theme 1: Peoples' Unamenable Behavior}

In life, they are many circumstances that people possess different personal behavior. They may be a friend who is ready to help or will be the ones that cause you to stress (Danson \& Creed, 1970). Mushtaq \&Khan (2012) emphasize that an individual's environment can give a stressful vibe by giving unacceptable actions or words. These factors are the preservice teachers' challenges in a laboratory school from the supervising teacher educator, pupils, parents, and oneself.

"Toxic teachers who doesn't understand a situation of a practice teacher as if they weren't in the same position years ago". [P6, L113, P4]

"Pupils who are not listening while you were discussing". [P8, L119, P4]

"Waking up early and staying up late at night. And mostly, those parents with so many rants". [P7, L115, P4]

"When the teacher has to be blamed by the parents when something happened on their child which is also their responsibility". [P1, L104, L4]

\subsubsection{Theme 2: Financial Shortage}

Some of the preservice teachers are not living in a city; thus, they need to look for a shelter to safely sleep and study to finish school at the given time (Joo et al., 2008). They also need a transportation allowance to travel from their house to university to do their practice teaching. They also need to have laptops or computers since this will help them ease their requirements, particularly making lesson plans and multimedia instructional materials. Daily allowance must also be given to them by their parents to use for their necessities. Indeed, Worthy, S. et al. (2010) said the financial crisis in college students is familiar to their age since they need necessary things to study well.

"Making my instructional materials because I don't have my own laptop". [P2,L124, P4]

"Transportation especially from our place to my assigned school". [P5, L131, P5]

"The difficulties I've faced in my practice teaching are the following: first financial, transportation and also in terms of boarding". [P10, L138, P5]

\subsubsection{Theme 3: Vigorous School Demands}

According to Ostberg et al. (2018), giving stress to the future educator, particularly school demands, can cause them to perform less during their practicum. These practicum requirements from supervising teachers can make preservice teachers more stressable. Doing weekly school tasks as lesson planning and instructional materials simultaneously give them struggle during this period. Observing proper classroom management is expected to get high grades during their actual teaching demonstration that others think just to quit because they did not prepare themselves ahead of time.

"The difficulties I face in my practice teaching was making a lesson plan and making my instructional materials because I don't have my own laptop". [P2,

L124, P4]

"Making lesson plan because I don't know if it will suit to the topic and if it will work. Also the classroom management". [P7, L134, P5]

"The most difficult part for me during my practice teaching is doing the classroom management". [P1, L124, P4] 


\subsection{Preservice Teachers' Coping Mechanisms}

\subsubsection{Theme 1: Implementation of Diverse Teaching Strategies}

In the study of Moore (2003) that preservice teachers scrutinize concepts into practice during their practicum. The following are expected in teaching, especially in giving well-comprehensive lesson plans and content, preparing attractive and creative instructional materials, procedural concerns of time management, and classroom management. Finding appropriate teaching strategies is given the focus on the practicum experience for the preservice teachers.

"I deliver my lessons using eye catching Instructional materials, and also by using games or gamification strategy, that helps the classroom environment more active and not passive". [P1, L60, P2]

"Most of the time, I deliver my lessons through inductive method and using multimedia as my instructional materials. Also, I used some strategies for my pupils to listenattentively". [P5, L69, P3]

I deliver it using my instructional materials like manila paper and also, I use power-point presentation". [P4, L67, P3]

\subsubsection{Theme 2: Possess Adequate Personality}

Being a preservice teacher encounter many different situations, but they need to manage it with a strong personality and independently to be a successful individual. Schwarzer (2014) defines self-worth as more significant in handling a difficult situation and understanding oneself more without panic. The study of Heslin \& Klehe (2006) also agreed that self-knowing is more effective in completing a challenging task and focus on achieving them.

"I deal them by just being calm and positive or optimistic that despite of not having my resources I find ways by being calm with myself and of course through the help of God's favor and by praying". [P2, L145, P5]

"Just relax and think so many solutions for me to overcome my difficulties". [P7, L151, P5]

"Relax breath in and breathe out, and always look at the brighter side". [P9, L156, P5]

"Research the strategies on how to manage the behavior of the pupils inside the classroom". [P8, L154, P5]

"I am dealing with the classroom management, the only thing I did to get and keep their attention on me and on my lesson is by giving them points and prizes". [P1, L141, P5]

\subsubsection{Theme 3: Seek Out Spiritual Guidance}

All of us experience difficult times, but those times we seek guidance coming from above. When preservice teachers experience situations out of their control, they offer it to the Almighty, who always ready to listen to them. To seek spiritual guidance, make things so light, and soon everything will be okay. Scott (2009) \& Fincham et al. (2008) emphasized seeking help from above us when things are rough is an ordinary act of a person who possesses a sincere faith. As mentioned in the study of Luhrman \& Morgain (2012), a person who has more spiritual beliefs tends to be more assertive and cannot give up on the challenges easily.

"By those difficulties I've faced during my practice teaching I'd faced it by simply having confidence and trust to Almighty God that I can finish and overcome it all". [P10, L158, P5]

"I just prayed and also some help from God". [P3, L147, P5]

"I deal them by just being calm and positive or optimistic that despite of not

having my resources, I find ways by being calm with myself and of course through the help of God's favor and by praying". [P2, L145, P5]

\section{Conclusion}

Success can be achieved by self-determination and the encouragement provided by individuals around them. Although, there are issues to address, such as unwanted peoples' behavior, overlapping schoolwork demands, and financial deficiencies that influence preservice teachers' performance, which is essential to obtain meaningful results. The identified parameters affecting pre-service teachers' academic progress improve and strengthen pedagogical teaching approaches. Therefore, academes in educational institutions must set their practice teaching period into a productive and meaningful area to support student teachers who have encountered financial support shortages and teaching delivery difficulties.

The following recommendations are made for preservice teachers, supervising teacher educators, and future researchers. First, to the preservice teachers, they should not view teaching experience as an area of tension but as an avenue to enhance and improve teaching methods and strategies beneficial for future teaching careers. Next, for supervising teacher-educators have to be mindful that preservice teachers are also students who need proper guidance in lesson planning and actual teaching demonstration in terms of instructional methods and classroom management. Support and appropriate assessment to the preservice teachers will produce knowledgeable and competent future teachers who can educate diverse learners. Lastly, researchers may use this study in finding other variables that influence the preservice teachers' performance in the laboratory school.

\section{References}

i. Ahmad, S., Ch, A. H., Batool, A., Sittar, K., \& Malik, M. (2016). Play and Cognitive Development: Formal Operational Perspective of Piaget's Theory. Journal of Education and Practice, 7(28), 72-79.

ii. Alieto, E., Abequibel, B., Ricohermoso, C., \& Alieto, E. O (2020). An Investigation on Digital and Print Reading Attitudes: Samples from Filipino Preservice Teachers from a Non-metropolitan-based University.

iii. Baxter, P., \& Jack, S. (2008). Qualitative case study methodology: Study design and implementation for novice researchers. The qualitative report, 13(4), 544-559. 
iv. Boe, E. E., Shin, S., \& Cook, L. H. (2007). Does teacher preparation matter for beginning teachers in either special or general education? The journal of special education, 41(3), 158-170.

v. Brush, T., \& Saye, J. (2009). Strategies for preparing preservice social studies teachers to effectively integrate technology: Models and practices. Contemporary issues in technology and teacher education, 9(1), 46-59.

vi. Chao, C. N. G., Forlin, C., \& Ho, F. C. (2016). Improving teaching self-efficacy for teachers in inclusive classrooms in Hong Kong. International Journal of Inclusive Education, 20(11), 1142-1154.

vii. Chen, J. L., \& Mensah, F. M. (2018). Teaching contexts that influence elementary preservice teachers' teacher and science teacher identity development. Journal of Science Teacher Education, 29(5), 420-439.

viii. Danson, C., \& Creed, T. (1970). RATE OF RESPONSE AS A VISUAL SOCIAL STIMULUS 1. Journal of the experimental analysis of behavior, 13(2), 233-242.

ix. Darling-Hammond, L. (2008). Reshaping teaching policy, preparation, and practice: Influences of the National Board for Professional Teaching Standards. Emerald Group Publishing Limited.

X. Evans, M. P. (2013). Educating preservice teachers for family, school, and community engagement. Teaching Education, 24(2), 123-133.

xi. Farrell, T. S. (2002). Lesson planning. Methodology in language teaching: An anthology of current practice, 30-39.

xii. Feiman-Nemser, S. (2001). From preparation to practice: Designing a continuum to strengthen and sustain teaching.

xiii. Ferguson, A., \& Peterson, P. (2002). Intonation in partner accommodation for aphasia: A descriptive single case study. Journal of communication disorders, 35(1), 11-30.

xiv. Fincham, F. D., Beach, S. R., Lambert, N., Stillman, T., \& Braithwaite, S. (2008). Spiritual behaviors and relationship satisfaction: A critical analysis of the role of prayer. Journal of social and clinical psychology, 27(4), 362- 388.

xv. Friedman, A. J., Cosby, R., Boyko, S., Hatton-Bauer, J., \& Turnbull, G. (2011). Effective teaching strategies and methods of delivery for patient education: a systematic review and practice guideline recommendations. Journal of Cancer Education, 26(1), 12-21.

xvi. Grossman, P., Hammerness, K., \& McDonald, M. (2009). Redefining teaching, re-imagining teacher education. Teachers and Teaching: theory and practice, 15(2), 273-289.

xvii. Grossman, P., Compton, C., Igra, D., Ronfeldt, M., Shahan, E., \& Williamson, P. (2009). Teaching practice: A crossprofessional perspective. Teachers College Record, 111(9), 2055-2100.

xviii. Harris, A., \& Goodall, J. (2008). Do parents know they matter? Engaging all parents in learning. Educational research, 50(3), 277-289.

xix. Heslin, P. A., \& Klehe, U. C. (2006). Self-efficacy. Encyclopedia of Industrial/Organizational Psychology, SG Rogelberg, ed, 2, 705-708.

xx. Innovate My School. (2013, January 18). The 10 most important teaching strategies. Retrieved from http://www.globalpuzzle.net/l:http://www.innovatemyschool.com/ideas/the-10-most-powerful-teaching strategies.

xxi. JamaliNasari, A., \& Heidari, M. (2014). The important role of lesson plan on educational achievement of Iranian EFL teachers' attitudes. International Journal of Foreign Language Teaching and Research, 2(5), 27-34.

xxii. Johnson, D. (2010). Learning to Teach: The Influence of a University-School Partnership Project on Pre-Service Elementary Teachers' Efficacy for Literacy Instruction. Reading Horizons, 50(1).

xxiii. Joo, S. H., Durband, D. B., \& Grable, J. (2008). The academic impact of financial stress on college students. Journal of College Student Retention: Research, Theory \& Practice, 10(3), 287-305.

xxiv. Kennedy, K., \& Archambault, L. (2012). Offering preservice teachers field experiences in K-12 online learning: A national survey of teacher education programs. Journal of Teacher Education, 63(3), 185-200.

xxv. Kiggundu, E. (2007). Teaching practice in the Greater Vaal Triangle Area: The student teachers experience. Journal of College Teaching \& Learning (TLC), 4(6).

xxvi. Kormos, J., \& Nijakowska, J. (2017). Inclusive practices in teaching students with dyslexia: Second language teachers' concerns, attitudes and self-efficacy beliefs on a massive open online learning course. Teaching and Teacher Education, 68, 30-41.

xxvii. Lampert, M. (2010). Learning teaching in, from, and for practice: What do we mean?. Journal of teacher education, 61(1-2), 21-34.

xxviii. Lave, J. (2009). The practice of learning. Contemporary theories of learning, 200-208.

xxix. Luhrmann, T. M., \& Morgain, R. (2012). Prayer as inner sense cultivation: An attentional learning theory of spiritual experience. Ethos, 40(4), 359-389.

xxx. Luszczynska, A., \& Schwarzer, R. (2005). Social cognitive theory. Predicting health behaviour, 2, 127-169.

xxxi. Mann, R. L. (2006). Effective teaching strategies for gifted/learning-disabled students with spatial strengths. Journal of Secondary Gifted Education, 17(2), 112-121.

xxxii. Mapfumo, J. S., Chitsiko, N., \& Chireshe, R. (2012). Teaching practice generated stressors and coping mechanisms among student teachers in Zimbabwe. South African Journal of Education, 32(2), 155-166.

xxxiii. Marks, M. J., Binkley, R., \& Daly, J. K. (2014). Preservice teachers and religion: Serious gaps in religious knowledge and the First Amendment. The Social Studies, 105(5), 245-256.

xxxiv. Matviienko, O. (2014). Theoretical Basics of Preparation of Teachers to Pedagogical Interaction with Children of Various Age.

xxxv. McDonnough, J. T., \&Matkins, J. J. (2010). The role of field experience in elementary preservice teachers' self-efficacy and ability to connect research to practice. School Science and Mathematics, 110(1), 13-23.

xxxvi. Moore, R. (2003). Reexamining the field experiences of preservice teachers. Journal of Teacher Education, 54(1), 3142.

xxxvii. Mushtaq, I., \& Khan, S. N. (2012). Factors Affecting Studentsâ€ ${ }^{\mathrm{TM}}$ Academic Performance. Global journal of management and business research, 12(9). 
xxxviii. Ogunsola, O. K., Osuolale, K. A., \& Ojo, A. O. (2014). Parental and related factors affecting students' academic achievement in Oyo State, Nigeria. International Journal of Social, Behavioral, Educational, Economic, Business and Industrial Engineering, 8(9), 3129-3136.

xxxix. Östberg, V., Plenty, S., Låftman, S. B., Modin, B., \& Lindfors, P. (2018). School Demands and Coping ResourcesAssociations with Multiple Measures of Stress in Mid-Adolescent Girls and Boys. International journal of environmental research and public health, 15(10), 2143.

xl. Peebles, J. L., \& Mendaglio, S. (2014). The impact of direct experience on preservice teachers' self-efficacy for teaching in inclusive classrooms. International Journal of Inclusive Education, 18(12), 1321-1336.

xli. Piaget, J. (1972). Intellectual evolution from adolescence to adulthood. Human development, 15(1), 1-12. Bandura, A. (1999). Social cognitive theory of personality. Handbook of personality, 2, 154-96.

xlii. Putman, S. M. (2009). Grappling with classroom management: The orientations of preservice teachers and impact of student teaching. The Teacher Educator, 44(4), 232-247.

xliii. Rakicioglu-Soylemez, A., \& Eroz-Tuga, B. (2014). Mentoring expectations and experiences of prospective and cooperating teachers during practice teaching. Australian Journal of Teacher Education, 39(10), n10.

xliv. Reupert, A., \& Woodcock, S. (2010). Success and near misses: Pre-service teachers' use, confidence and success in various classroom management strategies. Teaching and Teacher Education, 26(6), 1261-1268.

xlv. Riedler, M., \& Eryaman, M. Y. (2016). Complexity, diversity and ambiguity in teaching and teacher education: Practical wisdom, pedagogical fitness and tact of teaching. International Journal of Progressive Education, 12(3), 172-186.

xlvi. Rieg, S. A., Paquette, K. R., \& Chen, Y. (2007). Coping With Stress: An Investigation of Novice Teachers' stressors In the Elementary Classroom. Education, 128(2).

xlvii. Rosas, C., \& West, M. (2009). Teachers Beliefs about Classroom Management: Pre-service and Inservice Teachers' Beliefs about Classroom Management. International Journal of Applied Educational Studies, 5(1).

xlviii. Rusznyak, L., \& Walton, E. (2011). Lesson planning guidelines for student teachers: A scaffold for the development of pedagogical content knowledge. Education as change, 15(2), 271-285.

xlix. Schwarzer, R. (Ed.). (2014). Self-efficacy: Thought control of action. Taylor \& Francis.

l. Scott, R. G. (2009, November). To acquire spiritual guidance. In 179th Semiannual LDS General Conference. Salt Lake City.

li. Sharma, U., Forlin, C., Loreman, T., \& Earle, C. (2006). Pre-Service Teachers' Attitudes, Concerns and Sentiments about Inclusive Education: An International Comparison of Novice Pre-Service Teachers. International journal of special education, 21(2), 80-93.

lii. Shaukat, S., Sharma, U., \&Furlonger, B. (2013). Pakistani and Australian Pre-Service Teachers' Attitudes and SelfEfficacy Towards Inclusive Education. Journal of Behavioural Sciences, 23(2).

liii. Shen, B., McCaughtry, N., \& Martin, J. (2007). The influence of self-determination in physical education on leisuretime physical activity behavior. Research Quarterly for Exercise and Sport, 78(4), 328-338.

liv. Shulman, L. (1987). Knowledge and teaching: Foundations of the new reform. Harvard educational review, 57(1), 123.

lv. Stuart, C., \& Thurlow, D. (2000). Making it their own: Preservice teachers' experiences, beliefs, and classroom practices. Journal of teacher education, 51(2), 113-121.

lvi. Subedi, B. (2006). Preservice teachers' beliefs and practices: Religion and religious diversity. Equity \& Excellence in Education, 39(3), 227-238.

lvii. Ten Dam, G., \& Volman, M. (2004). Critical thinking as a citizenship competence: teaching strategies. Learning and instruction, 14(4), 359-379.

lviii. Unal, Z., \& Unal, A. (2017). Comparison of student performance, student perception, and teacher satisfaction with traditional versus flipped classroom models. International Journal of Instruction, 10(4), 145-164.

lix. Van Driel, J. H., Jong, O. D., \&Verloop, N. (2002). The development of preservice chemistry teachers' pedagogical content knowledge. Science Education, 86(4), 572-590.

lx. Visande, J. C. (2014). Developing Critical Thinking Skills among Education Students through Formative Education.

lxi. Worthy, S. L., Jonkman, J., \&Blinn-Pike, L. (2010). Sensation seeking, risk-taking, and problematic financial behaviors of college students. Journal of Family and Economic Issues, 31(2), 161-170.

lxii. Wa-Mbaleka, S. (2018). Writing your thesis and dissertation qualitatively: Fear No More. Silang, Cavite: OikosBiblios Publishing House.

lxiii. White, K. R. (2009). Connecting religion and teacher identity: The unexplored relationship between teachers and religion in public schools. Teaching and teacher education, 25(6), 857-866.

lxiv. Wilcox, S. K., Schram, P., Lappan, G., \& Lanier, P. (1991). The role of a learning community in changing preservice preservice teachers' knowledge and beliefs about mathematics education. For the Learning of Mathematics, 11(3), 31-39.

lxv. Yarmatov, R., \&Akhmedova, M. (2020). Preparation of Future History Teachers for Pedagogical Practice in Pedagogical Institutions of Higher Education. АрхивНаучныхПубликаций JSPI.

lxvi. Zeichner, K. M. (1987). Preparing reflective teachers: An overview of instructional strategies, which have been employed in preservice teacher education. International journal of educational research, 11(5), 565-575.

lxvii. Zeichner, K. (2012). The turn once again toward practice-based teacher education. Journal of Teacher Education, 63(5), 376-382. 